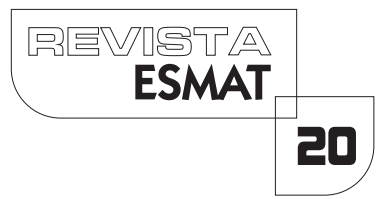

\title{
A SANÇÃO POLÍTICA COMO FORMA DE COMBATER A CORRUPÇÃO NO DIREITO TRIBUTÁRIO
}

\author{
POLITICAL SANCTION AS A WAY TO COMBAT CORRUPTION IN TAX LAW
}

NINA GABRIELA ${ }^{1}$

CHARLES DE SOUSA TRIGUEIRO ${ }^{2}$

\begin{abstract}
RESUMO
O presente artigo pretende estudar a validade acerca da aplicação das Sanções Políticas, vistas como restrições ou proibições impostas ao contribuinte, a fim de compeli-lo ao pagamento do tributo devido. Tais sanções foram consideradas inconstitucionais pelo Supremo Tribunal Federal; todavia, a citada Corte Suprema considerou válida a restrição do estabelecimento em um caso específico, ao verificar o histórico de inadimplência por parte de determinada empresa. A partir de então, surge a presunção de que o Supremo Tribunal Federal estaria alterando a sua histórica e consolidada decisão. Desse modo, a fim de responder a tal questionamento, foram apresentados, neste artigo, vários julgados da Suprema Corte no tocante ao tema exposto, restando comprovado que o entendimento quanto à inconstitucionalidade da aplicação das sanções políticas não mudou ao permitir a interdição do estabelecimento, mas conferiu uma interpretação específica ao caso concreto.
\end{abstract}

PALAVRAS-CHAVE : Impostos. Sonegação Fiscal. Sanção. Interdição de Estabelecimento.

\begin{abstract}
This article aims to study the validity on applying sanction policies, which is seen as a restriction or prohibition imposed on the taxpayer in order to compel him to pay tribute. Such penalties were considered unconstitutional by the Supreme Court. However, the Supreme Court, considered valid the restriction of establishment in a specific case. From then on, the Supreme Court reply would be to changing its consolidated decision. Thus, in order to respond such questions, it was presented in this article, several judged cases by the Supreme Court regarding the exposed subject, showing evidences that the understanding of unconstitutionality on applying sanction policies has not been changed in order to allow prohibition of establishment, but only gave a specific interpretation to the case.
\end{abstract}

KEYWORDS: Tax. Withholding Tax. Sancions. Proibition of Establishment.

\footnotetext{
${ }^{1}$ Mestre em Ciências Jurídicas e Políticas/Menção em Direito Fiscal, pela Faculdade de Direito da Universidade de Coimbra (FDUC). Especialista em Direito Tributário, pelo Instituto de Educação Continuada (IEC PUC Minas). Graduada em Direito, pela Universidade Católica de Minas Gerais. Atualmente, é professora da PósGraduação da Pontifícia Universidade Católica de Minas Gerais e da Faculdade Kennedy. Advogada e consultora do Escritório Borges \& Costa Advogados. ninagabrielabc@gmail.com

${ }^{2}$ Doutorando em direito Público na Universidade de Santiago de Compostela. Bacharel e mestre em Ciências Jurídicas e Sociais, pela Universidade Federal da Paraíba (UFPB).Técnico Administrativo em Educação na UFPB; charles.ufpb@hotmail.com
} 


\section{INTRODUÇÃO}

O presente estudo visa abordar a validade acerca da aplicação das chamadas "Sanções Políticas", vistas, pela maioria da doutrina, como uma restrição ou proibição imposta ao contribuinte, como forma indireta de obrigá-lo ao pagamento do tributo devido.

Essas sanções políticas foram consideradas inconstitucionais pelo Supremo Tribunal Federal, responsável pela criação de três súmulas ${ }^{3}$. Estas foram criadas com o intuito de coibir a utilização das sanções políticas como meio de garantir o cumprimento da obrigação tributária por parte do sujeito passivo.

Para alguns doutrinadores, a utilização das sanções políticas representaria considerável abuso de poder por parte da Fazenda Pública, pois a simples condição de inadimplente não configuraria motivo suficiente para que fortes medidas restritivas fossem aplicadas. Outro forte argumento consiste no princípio da livre iniciativa, que assegura a todos o livre exercício de qualquer trabalho, ofício ou profissão. Com isso, qualquer restrição que implicasse o cerceamento da liberdade de exercer a atividade lícita seria inconstitucional por contrariar o referido dispositivo.

Entretanto, esse entendimento, "teoricamente" pacificado, tem sofrido recentes inovações, haja vista o caso da empresa de cigarros América Virginia Tabacos, que teve seu estabelecimento interditado por meio do seu cancelamento de registro de fabricante devido à reiterada prática de inadimplemento fiscal.

O Supremo Tribunal Federal considerou válida a restrição do estabelecimento ao verificar o histórico de inadimplência por parte da referida empresa, que possuía um débito de mais de 1,42 bilhões em tributos não pagos.

Diante de tal fato, surge a seguinte indagação: Estaria o Supremo Tribunal Federal alterando seu histórico e consolidado entendimento em considerar inconstitucional qualquer ato estatal com o escopo de compelir o contribuinte ao pagamento do tributo devido?

A fim de responder a tal questionamento, serão apresentados vários julgados do Supremo Tribunal Federal no que tange ao tema exposto, até mesmo aos posteriores ao julgamento da empresa de cigarros América Virginia Tabacos.

${ }^{3}$ BRASIL. Supremo Tribunal Federal. Súmulas 70, 323, 547. 


\section{DAS SANÇÕES}

\subsection{Conceito e finalidade das sanções.}

Antes de adentrar ao tema, "Sanções Políticas", é mister destacar o significado, a finalidade, bem como a classificação das sanções no ordenamento jurídico pátrio.

Beccaria (1985, p. 25) sustenta a tese de que nenhuma pessoa faz o sacrifício em prol da proteção do interesse público. A necessidade da aplicação da pena é vista por ele como o único meio hábil para controlar as paixões humanas, as quais contrariam a estabilidade social. Assim, quem não respeitasse a lei pelas virtudes de seu caráter, faria pelo temor das penas. A aplicação da sanção é vista pelo autor como um mal necessário, devendo ser utilizada até o limite de sua necessidade, a fim de evitar agressão à lei.

Nesse sentido, a sanção passa a ser vista como uma consequência à violação de uma norma prescritiva implícita em todo o ordenamento jurídico, servindo de salvaguarda das leis contra as condutas opostas aos seus comandos, tendo a finalidade de reforçar a eficácia do ordenamento jurídico, bem como de evitar ou inibir a ocorrência de violação às normas (BOBBIO, 1999, p. 189).

As sanções desempenham várias funções no mundo jurídico, como, por exemplo, as funções: preventiva; repressiva; reparatória; didática; e premial.

A sanção visa desestimular o rompimento da ordem jurídica pela intimidação de seus possíveis infratores a se sujeitarem a seus indesejáveis efeitos. De tal modo, a sanção age preventivamente a fim de reforçar a eficácia das normas jurídicas, no intuito de evitar ou desestimular sua violação. Em relação à função repressiva, tem-se que nesta se encontra a punição imposta ao infrator, ou seja, a sanção aplicada estabelece um castigo como solução à conduta delituosa. Algumas sanções almejam, também, a indenização do dano ocasionado à vítima do ato ilícito, impondo ao infrator o dever de repará-lo, como, por exemplo, as sanções civis, as quais visam à compensação de determinado bem material, por meio do ressarcimento em dinheiro pela avaliação da extensão do dano causado. As sanções apresentam, ainda, a função didática, pois esta deverá contribuir para a educação e a correção do perpetrante (SILVA, 2010, p. 69). Entretanto, conforme já observado por Kelsen (2003), a sanção não possui apenas a função punitiva, mas também sua função incentivadora, pois ela poderá advir como consequência de atos e fatos convenientes ao ordenamento jurídico pátrio.

A partir de então, pode-se concluir que a sanção poderá consistir tanto em uma resposta do Estado contra a transgressão de uma norma jurídica, a fim de reprimir, prevenir, 
reparar ou educar, quanto possuir a função incetivadora, no intuito de induzir o comportamento ou cumprimento de determinada norma jurídica. Assim, havendo a constatação acerca da ocorrência de determinado fato, ilícito, ou não, deverá ser aplicada determinada sanção, com vista a assegurar a eficácia do ordenamento jurídico, bem como manter a estabilidade social.

Para Paulo Roberto Coimbra Silva (2010, p. 88), as sanções se dividem em: civil, comercial, trabalhista, penal, administrativa ou tributária. O que irá definir qual tipo de sanção aplicada será a norma jurídica infringida, seja ela civil, comercial, administrativa etc. A grande prova disso, segundo o autor, consiste na sanção aplicada ao devedor de alimentos no Brasil, ou seja, àquele que não cumpre o dever de prestar alimentos, é aplicada como sanção: a prisão. Todavia, neste caso, não será uma prisão penal, mas sim uma prisão civil, uma vez que a norma jurídica infringida foi a constante no Código Civil.

No que diz respeito às sanções tributárias, tem-se que o Estado impõe à sociedade a obrigação de dar dinheiro, no intuito de prover recursos necessários à sua manutenção. Essa obrigação, que se denomina tributo, é compulsória, e para ser cumprida exige-se a previsão de uma sanção a ser aplicada no caso de seu descumprimento.

As sanções tributárias imputadas têm como pressuposto a realização de uma ação ou omissão tipificada pela legislação fiscal como infração tributária. Trata-se, pois, do inadimplemento de uma obrigação tributária principal ou acessória (SILVA, 2010, p. 111).

Desse modo, a sanção no âmbito do direito tributário vem sendo utilizada como elemento intimidatório capaz de obrigar o contribuinte a cumprir determinada obrigação fiscal, efetuando, por exemplo, o pagamento do tributo. Com isso, o contribuinte que não pagar os seus impostos devidos, sofrerá as consequentes penalidades.

\subsection{Ilícito Fiscal x Natureza Jurídica}

Conforme sabido, o cometimento de um ilícito pode ocorrer em qualquer ramo do direito, existindo, assim, ilícitos no âmbito civil; administrativo; comercial; eleitoral; tributário etc., gerando como consequência a incidência de uma sanção.

Partindo dessa premissa, o ilícito passa a ser visto como todo ato comissivo ou omissivo que infringe um dever jurídico. O ilícito tributário que não difere ontologicamente dos demais, mas tão somente em razão do grau ou quanto à sua estrutura normativa, irá advir de um descumprimento de certa obrigação tributária, que irá gerar consequências perante o Estado. 
A par disso, surge uma grande discussão doutrinária em relação à natureza jurídica desse ilícito, ou seja, este ilícito possui natureza administrativa ou penal?

Há autores que sustentam a natureza administrativa dos ilícitos fiscais, como é o caso do doutrinador alemão Goldschmidt, que afasta fortemente as infrações tributárias do âmbito penal, e o faz pelos seguintes argumentos: i) que não seria possível aplicar uma sanção penal senão pelo Poder Judiciário; ii) que as penas criminais são incomunicáveis, mas as sanções administrativas ou tributárias admitem, em determinados casos, a possibilidade de suas exigências aos sucessores do infrator; iii) que no direito penal não se admite o reformatio in pejus, suscetível de ocorrer a revisão pela administração; entre outros (SILVA, 2010, p. 135).

Contudo, existem autores que defendem: i) que as infrações tributárias estariam fundidas ao Direito Penal, visto que os bens jurídicos tutelados pela administração tributária também estariam tutelados pelo Direito Penal; ii) que os castigos impostos aos infratores, como a multa, têm nítida feição punitiva; iii) que, apesar de as sanções tributárias serem aplicadas por autoridades administrativas, estas consistem em genuínas penas, pois infringem aos infratores sacrifícios com propósitos punitivos, repressivos, corretivos e intimidador; e iv) que as sanções tributárias, assim como as penais, são manifestações do ius puniendi estatal, único e unitário (SAINZ DE BUJANDA, 1985, p.6). Assim, foi em razão desses argumentos que em diversos países da Europa prevaleceu essa corrente.

$\mathrm{Na}$ França, tanto a doutrina quanto a jurisprudência reconhecem a identidade substancial entre a repressão penal e administrativa. A jurisprudência francesa tem reconhecido a necessidade de enriquecer o regime jurídico próprio da Administração com técnicas de procedência do Direito Penal (PEREZ, 1992, p. 31).

Já na Espanha, a doutrina e a jurisprudência reconhecem a natureza penal das infrações não delituosas em virtude de sua identidade ontológica com aquelas criminosas. $\mathrm{O}$ Tribunal Supremo da Espanha, a exemplo de seu Tribunal Constitucional, há muito acatou a ideia de unidade da pretensão punitiva do Estado, que pressupõe a negação de qualquer diferença substancial entre ilícito administrativo e penal.

$\mathrm{Na}$ Itália também acabou por fazer prevalecer idêntico entendimento, além de Portugal, pois o direito lusitano caminhou contestando qualquer distinção ontológica e formal entre infrações fiscais tipificadas, ou não, pelo legislador penal. Nesse sentido, Nuno Sá Gomes (2000, p. 237) esclarece as peculiaridades existentes no Direito português, destacando estarem as contraordenações e as infrações inseridas no Direito penal fiscal. Assim, em diversos países da Europa, como Alemanha, França, Itália, Espanha e Portugal, prepondera o 
entendimento de não subsistirem diferenças ontológicas entre ilícitos penais ou administrativos, decorrendo ambos do poder unitário e indivisível do Estado.

Para o Direito brasileiro, contudo, o ilícito fiscal não possui relação com o ilícito de natureza penal, pois se trata de institutos distintos que possuem peculiaridades próprias no que se refere à natureza da sanção aplicada; à competência da autoridade para a respectiva aplicação; ao tipo de sanção aplicada; e ao processo de apuração do ilícito para a condenação do infrator.

Com isso, ao contrário do entendimento dominante na Europa, não há possibilidade de o ilícito fiscal e o ilícito penal possuírem a mesma natureza jurídica, nem derivarem de um poder sancionador unitário, estarem fundidos em um único ramo do direito, tampouco se sujeitarem a um mesmo regime jurídico. Pois, não obstante existam ilícitos civis, comerciais, trabalhistas ou tributários, todos eles podem ensejar a aplicação de uma sanção com a função punitiva, mas nem por isso terão natureza penal, uma vez que a repressão não é exclusividade do Direito penal. Apesar de ambos se sujeitarem a princípios gerais de repressão, as sanções fiscais, diferentemente das penais, derivam da ius tributandi, e não do ius puniendi (SILVA, 2010, p. 148, 149).

Há autores que classificam o ilícito tributário em duas espécies: a infração tributária e a infração penal. Aquela é decorrente da inobservância da legislação tributária, como ocorre com o pagamento incorreto do tributo. Esta ocorrerá quando o fato praticado implicar apenas violação à lei penal, como no caso do fiscal que exige tributo que sabe ser indevido.

Dessarte, no ordenamento jurídico brasileiro, os ilícitos fiscais consistem em infrações à legislação tributária, tais quais definidas no artigo 96 do Código Tributário $\mathrm{Nacional}^{4}$, produzindo, assim, a aplicação de sanções administrativas cujas consequências compreendem em multas pecuniárias ou outras medidas como, por exemplo: a interdição do estabelecimento, apreensão de mercadorias (objeto do nosso estudo), além de outros meios de coerção utilizados com o único fim de receber os créditos tributários, não possuindo relação com a sanção de natureza penal. Haverá, contudo, atos que, embora sejam contra a ordem tributária, ensejam a aplicação de uma sanção de natureza penal, haja vista estarem eles tipificados como crime no Código Penal, no caso, o cometimento de um ilícito penal, e não um ilícito tributário.

\footnotetext{
${ }^{4}$ Art. 96. A expressão "legislação tributária" compreende as leis, os tratados e as convenções internacionais, os decretos e as normas complementares que versem, no todo ou em parte, sobre tributos e relações jurídicas a eles pertinentes. BRASIL. Constituição (1988). Constituição da República Federativa do Brasil: Senado, 1988.
} 


\section{SANÇÕES POLÍTICAS}

No que se refere às sanções tributárias, merecem destaque as chamadas "sanções políticas", as quais apresentam diversos tipos de enquadramento no cenário jurídico brasileiro.

As sanções políticas consistem nas restrições ou proibições impostas ao contribuinte como forma indireta de obrigá-lo ao pagamento de tributo, como, por exemplo, os casos de apreensões de mercadorias e documentos e interdição do estabelecimento (MACHADO, 1998, p. 47).

A sanção política existente no Brasil busca alcançar interesses arrecadatórios da Fazenda Pública por meio de medidas indiretas e punitivas do Estado, tratando-se do uso de meios diversos daqueles juridicamente disponíveis para que o contribuinte seja coagido a cumprir uma obrigação (GANDARA, 2012, p. 37).

Em outras palavras, e tentando trazer um conceito simples de sanções políticas, têmse estas como restrições impostas pela Administração Pública contra o contribuinte em face do não pagamento do tributo ao fisco, o qual tem por objetivo deixar de lado a Execução Fiscal para o recebimento do crédito tributário. Todavia, para a compreensão acerca das sanções políticas, é mister apontar os fatores históricos em que tal instituto foi criado.

No que tange à aplicação das referidas sanções políticas, o Supremo Tribunal Federal possui entendimento consolidado há várias décadas. Entendimento este responsável pela edição das Súmulas $70^{5}, 323^{6}$ e $547^{7}$, criadas a partir das reiteradas práticas abusivas levadas à Suprema Corte.

No julgamento do Recurso de Mandado de Segurança nº 9.698, de 1962, o Supremo Tribunal Federal já se posicionava sobre não ser lícito ao fisco interditar o estabelecimento comercial no intuito de obrigar os contribuintes a pagar o imposto devido, visto ter o Estado meios possíveis de cobrança, como a Execução Fiscal. Tal Julgado contribuiu para a edição da Súmula $n^{\circ} 70$, sendo que na mesma sessão plenária houve, ainda, a edição da Súmula ${ }^{\circ}$

\footnotetext{
${ }^{5}$ BRASIL. Supremo Tribunal Federal. Súmula 70 - É inadmissível a interdição de estabelecimento como meio coercitivo para cobrança de tributo. Súmula da Jurisprudência Predominante do Supremo Tribunal Federal: Anexo ao Regimento Interno. Edição: Imprensa Nacional, 1964a, p. 56.

${ }^{6}$ BRASIL. Supremo Tribunal Federal. Súmula 323 - É inadmissível a apreensão de mercadorias como meio coercitivo para pagamento de tributos. Súmula da Jurisprudência Predominante do Supremo Tribunal Federal: Anexo ao Regimento Interno. Edição: Imprensa Nacional, 1964b, p. 143.

${ }^{7}$ BRASIL. Supremo Tribunal Federal. Súmula 547 - Não é lícito à autoridade proibir que o contribuinte em débito adquira estampilhas, despache mercadorias nas alfândegas e exerça suas atividades profissionais. Diário de Justiça da União, Brasília, 10 de dezembro de 1969, p. 5.935.
} 
323, a qual tratava de matéria semelhante ao vedar a apreensão de mercadorias como forma coercitiva para cobrança de tributo (BARROS, 2010, p. 158).

Após alguns anos, em 1969, o Supremo Tribunal Federal voltou a ser chamado para resolver o mesmo tema, e os Recursos Extraordinários $n^{\text {os }}$ 63.045, 60.664 e 63.047 deram origem a uma nova Súmula, qual seja: a Súmula n ${ }^{\circ} 547$, aprovada em sessão plenária, em 3 de dezembro de 1969.

A partir da edição de tais Súmulas, surgem vários estudiosos que passaram a repelir incessantemente a aplicação das sanções políticas aos devedores tributários, sob o argumento de se tratar de ato ilegal ou abusivo cometido pela Fazenda Pública, a fim de compelir o contribuinte em débito ao pagamento do tributo.

Trata-se de um comportamento que a Fazenda Pública há muito adota, sempre com vista a uma arrecadação mais célere. São por meio dessas condutas que indiretamente as Fazendas Públicas exigem do contribuinte em débito com o Fisco o pagamento da dívida tributária. Todavia, conforme visto, tais atos já despertaram o interesse dos estudiosos que consideram essas práticas ilegais de sanções políticas, entendidas como fruto do "distorcido" exercício da autoridade inserida no Poder Executivo.

Os autores, os quais repelem a aplicação das sanções políticas, como Hugo de Brito Machado, Leandro Paulsen, entre outros, argumentam no sentido de que essas práticas funcionam como forma indireta de Execução Fiscal, que contrariam flagrantemente os direitos e garantias fundamentais albergados pela vigente Constituição da República Federativa do Brasil (MACHADO, 2008, p. 89). Os autores afirmam, também, que qualquer restrição que implique cerceamento da liberdade de exercer a atividade lícita será inconstitucional por admitir que somente aqueles que pagam pontualmente os tributos tenham o direito ao exercício da atividade econômica (PAULSEN, 2009).

A prática da utilização das sanções políticas é rigorosamente repelida, haja vista que o contribuinte não pode ser impedido de exercer livremente as suas atividades pelo fato de estar inadimplente, representando total afronta aos artigos $5^{\circ}$, inciso XIII ${ }^{8}$, e 170, parágrafo único ${ }^{9}$, ambos da Constituição da República Federativa do Brasil.

Esse é também o entendimento Jurisprudencial, ao estabelecer que a retenção de mercadorias importadas na alfândega, a fim de assegurar o pagamento de tributos, é medida

${ }^{8} \mathrm{XIII}$ - é livre o exercício de qualquer trabalho, ofício ou profissão, atendidas as qualificações profissionais que a lei estabelecer. BRASIL. Constituição (1988). Constituição da República Federativa do Brasil: Senado, 1988.

${ }^{9}$ Parágrafo único. É assegurado a todos o livre exercício de qualquer atividade econômica, independentemente de autorização de órgãos públicos, salvo nos casos previstos em lei. BRASIL. Constituição (1988). Constituição da República Federativa do Brasil: Senado, 1988. 
que viola o livre exercício da atividade econômica, haja vista o ministro Marco Aurélio ${ }^{10}$ também ter ressaltado a "vetusta jurisprudência" do Supremo Tribunal Federal no sentido de impedir que o Estado exercite esse tipo de coação, pois, para ele, qualquer ato que implique forçar o cidadão a recolhimento de imposto é inconstitucional.

Apesar do entendimento pacificado pela doutrina e jurisprudência, esse voltou a ser debatido pelos estudiosos do Direito, no sentido de que o fisco pudesse aplicar algumas restrições, a depender do caso concreto, a fim de assegurar o cumprimento da obrigação tributária por parte dos devedores que se beneficiam dessas Súmulas para não pagarem impostos, de forma reiterada e fraudulenta, uma vez que o descumprimento da obrigação tributária gera fortes consequências perante as pessoas jurídicas que cumprem corretamente suas obrigações, ferindo gravemente alguns princípios constitucionais, como os princípios da isonomia; da livre concorrência; da boa fé; e da segurança jurídica.

Ao analisar o princípio da livre concorrência e isonomia, tem-se que todos devem ser tratados de forma igual, possuindo igualdade para competir no mercado, sob pena de violar o princípio da livre concorrência. Nesse sentido, se um agente econômico atua no mercado sendo menos onerado tributariamente que o outro que se encontra na mesma condição, estará infringindo tal princípio. Em relação ao princípio da boa-fé, este pressupõe a busca pelo cumprimento do direito e da justiça, o que não ocorre nos casos de empresas inadimplentes, pois estas buscam os lucros por meios arbitrários de concorrência desleal. Por fim, a relação entre o princípio da segurança jurídica e o princípio da livre iniciativa está no fato de vários autores levarem a ideia de livre iniciativa às últimas consequências, de forma que "o anarquismo prevaleça sobre a segurança jurídica". Assim, a livre-iniciativa, se ilimitada, pode gerar paradoxalmente o seu próprio fim, seja por monopólios e oligopólios, seja por cartéis.

\section{CASO AMÉRICA VIRG ÍNIA TABACOS}

Em 1995, foi criada a indústria de cigarros, conhecida como América Virgínia Indústria e Comércio, Importação e Exportação de Tabacos Ltda. A empresa, localizada em Nova Iguaçu, que deu início às suas atividades com dez funcionários, após sete anos da sua constituição, já possuía 550 funcionários diretos e mais 85 mil clientes no varejo.

\footnotetext{
${ }^{10}$ Ministro do Supremo Tribunal Federal
} 
O abrupto crescimento dessa empresa, em tão pouco tempo, chamou a atenção do Estado que decidiu fiscalizar o seu funcionamento, visto que havia fortes indícios de que o proprietário da empresa havia construído um império econômico utilizando-se de métodos duvidosos.

Após a apuração, a Receita Federal constatou que parte do faturamento da empresa advinha do inadimplemento fiscal, principalmente em relação ao Imposto sobre Produtos Industrializados (IPI). Isso porque a empresa não recolhia o referido imposto no valor de R\$ 0,46 centavos, por maço de cigarros.

Assim, em 2005, a América Virgínia Tabacos teve o registro de fabricante de cigarro cancelado por não recolher o IPI na Receita Federal, o que deu início a uma profunda celeuma judicial no que tange à validade da aplicação das "sanções políticas" neste caso concreto, tendo em vista a existência de má-fé da empresa desde o momento da sua constituição.

Após o cancelamento do seu registro, a empresa ajuizou Ação Cautelar perante o Tribunal Regional Federal da $2^{\text {a }}$ Região, a fim de que pudesse continuar exercendo suas atividades, independentemente do recolhimento dos tributos. Para tanto, a referida empresa, utilizou o argumento de que a Secretaria da Receita Federal estaria aplicando a chamada sanção política, inadmitida pelo ordenamento jurídico brasileiro.

Com o deferimento da medida cautelar e o acolhimento da ação principal, a União interpôs um Recurso de Apelação ( ${ }^{\circ}{ }^{2} 2005.51 .10 .007057$-3). Tal recurso interposto reformou a sentença, considerando válida a exigência imposta pela Secretaria da Receita Federal.

Contra a decisão proferida, a empresa opôs Recurso Extraordinário ao Supremo Tribunal Federal. Além disso, a empresa ajuizou também, no Supremo Tribunal Federal, Ação Cautelar, buscando efeito suspensivo ao citado recurso para que pudesse continuar exercendo suas atividades. Porém, apesar do pacificado entendimento de que as sanções políticas feriam o ordenamento jurídico brasileiro, de acordo com as Súmulas $n^{\text {os }} 70,323$ e 547, ao julgar a AC 1.657 MC/RJ, a Corte Maior resolveu, por maioria dos votos (sete votos a quatro), no sentido de cancelamento do registro especial no caso concreto, visto que o inadimplemento sistemático e isolado da obrigação tributária pela referida empresa acarreta comportamento ofensivo à livre concorrência devido à redução do preço de venda do produto no mercado.

EMENTA: Recurso Extraordinário. Inadmissibilidade. Estabelecimento industrial. Interdição pela Secretaria da Receita Federal. Fabricação de cigarros. Cancelamento do registro especial para produção. Legalidade aparente. Inadimplemento sistemático e isolado da obrigação de pagar Imposto sobre Produtos Industrializados - IPI. Comportamento ofensivo à livre concorrência. Singularidade do mercado e do 
caso. (...) consequente redução do preço de venda da mercadoria e ofensa à livre concorrência. (destaquenosso). (AC 1.657, Rel. Min. Joaquim Barbosa) $)^{11}$.

No seu voto, o ex-ministro Joaquim Barbosa ressaltou a preocupação em garantir o direito fundamental ao livre exercício da atividade econômica lícita, de modo que o cancelamento do registro especial compreende medida de extrema gravidade, cujos efeitos seriam difíceis reparar. O ex-ministro considerou, ainda, a importância acerca de tal julgamento, devido à mudança na orientação jurisprudencial já há muito adotado pela Suprema Corte.

O também ex-ministro Cezar Peluso, contudo, se opôs à decisão de Joaquim Barbosa, ao se manifestar no sentido de existir uma singularidade factual e normativa que expõe os consumidores e a livre concorrência ao periculum in mora. Cezar Peluso reconheceu a histórica jurisprudência em não aceitar o uso das sanções políticas, mas, segundo ele, no caso específico, não se aplicaria tal jurisprudência, sustentando sua teoria na busca pelo controle da produção e comercialização de cigarros, além de assegurar principalmente a livre concorrência.

No mesmo sentido, a ministra Carmen Lúcia segue o voto do ex-ministro Cezar Peluso, além de, Ricardo Lewandowski, Gilmar Mendes, Elen Grace, Carlos Brito e Eros Grau, sendo que este último salienta o caráter não absoluto do princípio da livre iniciativa, ou seja, segundo ele, "não seria legítimo resguardar o princípio da livre iniciativa de modo a vilipendiar outros princípios fundamentais".

O ministro Marco Aurélio e o ministro Celso de Mello e Sepúlveda Pertence, entretanto, acompanham o voto de Joaquim Barbosa, justificando a impossibilidade de fugir da sedimentada e consolidada jurisprudência formada pelo Supremo Tribunal Federal acerca da inconstitucionalidade de utilização das sanções políticas.

Em 22 de maio de 2013, foi julgado o Recurso Extraordinário $n^{\circ} 550.769$, sob a presidência do ex-ministro Joaquim Barbosa, e, por maioria de votos, decidiu por negar provimento ao recurso.

EMENTA: CONSTITUCIONAL. TRIBUTÁRIO. SANÇÃO POLÍTICA. NÃOPAGAMENTO DE TRIBUTO. INDÚSTRIA DO CIGARRO. REGISTRO ESPECIAL DE FUNCIONAMENTO. CASSAÇÃO. DECRETO-LEI 1.593/1977, ART. $2^{\circ}$, II. 1. Recurso extraordinário interposto de acórdão prolatado pelo Tribunal Regional Federal da $2^{\text {a }}$ Região, que reputou constitucional a exigência de rigorosa regularidade fiscal para manutenção do registro especial para fabricação e comercialização de cigarros (DL 1.593/1977, art. 2º , II). 2. Alegada contrariedade à

${ }^{11}$ BRASIL. Supremo Tribunal Federal. RECURSO Extraordinário. AC 1.657-6. Rel. ministro Cezar Peluso. Diário de Justiça da União, Brasília, 31 ago. 2007. 
proibição de sanções políticas em matéria tributária, entendidas como qualquer restrição ao direito fundamental de exercício de atividade econômica ou profissional lícita. Violação do art. 170 da Constituição, bem como dos princípios da proporcionalidade e da razoabilidade. 3. A orientação firmada pelo Supremo Tribunal Federal rechaça a aplicação de sanção política em matéria tributária. Contudo, para se caracterizar como sanção política, a norma extraída da interpretação do art. $2^{\circ}$, II, do Decreto-Lei $1.593 / 1977$ deve atentar contra os seguintes parâmetros: (1) relevância do valor dos créditos tributários em aberto, cujo não pagamento implica a restrição ao funcionamento da empresa; (2) manutenção proporcional e razoável do devido processo legal de controle do ato de aplicação da penalidade; e (3) manutenção proporcional e razoável do devido processo legal de controle da validade dos créditos tributários cujo não-pagamento implica a cassação do registro especial. 4. Circunstâncias que não foram demonstradas no caso em exame. 5. Recurso extraordinário conhecido, mas ao qual se nega provimento. (RE 550.769, Rel. Min. Joaquim Barbosa) ${ }^{12}$.

Um dos aspectos mais interessantes deste julgamento consistiu no voto apresentado por Joaquim Barbosa, que outrora se posicionou favorável ao recurso apresentado pela empresa de cigarros. Segundo o ex-ministro: "não há que se falar em sanção política se as restrições à prática de atividade econômica objetivam combater estruturas empresariais que têm na inadimplência tributária sistemática e consciente sua maior vantagem concorrencial".

Diante desse caso, cabe a seguinte indagação: Estaria o Supremo Tribunal Federal, alterando sua histórica orientação jurisprudencial que condenava as chamadas sanções políticas, passando a admiti-las em algumas situações?

A fim de responder a tal questionamento, serão apresentadas as recentes decisões, julgadas posteriormente à polêmica decisão do Supremo Tribunal Federal no que tange ao caso América Virgínia Tabacos.

\section{DEMAIS JULGADOS}

A $\mathrm{ADI} \mathrm{n}^{\circ} 173^{13}$ foi ajuizada pela Confederação Nacional da Indústria, e a $\mathrm{ADI} \mathrm{n}^{\circ}$ $394^{14}$ pelo Conselho Federal da Ordem dos Advogados do Brasil, que visavam declarar a

\footnotetext{
${ }^{12}$ BRASIL. Supremo Tribunal Federal. RECURSO EXTRAORDINÁRIO RE 550.769, Rel. Min. Joaquim Barbosa. 22 de maio de 2013.20 Disponível http://redir.stf.jus.br/paginadorpub/paginador.jsp?docTP=TP\&docID=5569814, acesso em: 2 de abril de 2018 . ${ }^{13}$ BRASIL. Supremo Tribunal Federal. Ação Direta de Inconstitucionalidade - ADI no 173 . Constitucional. Min. Rel. ministro Joaquim Barbosa. Diário de Justiça da União, Brasília, 20 mar. 2009. Disponível em:http://stf.jus.br/portal/diarioJustica/verDiarioProcesso.asp?numDj=53\&dataPublicacaoDj=20/03/2009\&incid ente $=1493516 \&$ codCapitulo $=5 \&$ numMateria $=7 \& \operatorname{codMateria}=1$

Acesso em: 29 de março de 2018.

${ }^{14}$ BRASIL. Supremo Tribunal Federal. Ação Direta de Inconstitucionalidade - ADI n ${ }^{\circ} 394$. Constitucional. Min. Rel. Joaquim Barbosa. Diário de Justiça da União, Brasília, 20 mar. 2009. Disponível em:
} 
inconstitucionalidade dos artigos $1^{\circ}$ e $2^{\circ}$ da Lei $n^{\circ} 7.711$, de 1988, pelo fato de esta prever a exigência da comprovação de regularidade fiscal nos casos de transferência de domicílio para o exterior, bem como a quitação dos créditos tributários para o registro ou arquivamento do contrato social ou atos análogos.

Ao considerar a intenção intimidatória da norma, por exigir quitação dos créditos tributários para que diversas atividades da empresa fossem convalidadas, o ex-ministro e relator do caso, Joaquim Barbosa, advertiu o sedimentado entendimento do Supremo Tribunal Federal, ao expor:

\begin{abstract}
"Esta Corte tem historicamente confirmado e garantido a proibição constitucional às sanções políticas, invocando, para tanto, o direito ao exercício de atividades econômicas e profissionais lícitas (art. 170, par. ún., da Constituição), a violação do devido processo legal manifestado no direito de acesso aos órgãos do Executivo ou do Judiciário, tanto para controle da validade dos créditos tributários, quanto para controle do próprio ato que culmina na restrição. É inequívoco, contudo, que a orientação firmada pelo Supremo Tribunal Federal não serve de escusa ao deliberado e temerário desrespeito à legislação tributária. Não há que se falar em sanção política se as restrições à prática de atividade econômica objetivam combater estruturas empresariais que têm na inadimplência tributária sistemática e consciente sua maior vantagem concorrencial. Para ser inconstitucional, a restrição ao exercício de atividade econômica deve ser desproporcional e não-razoável”(BARROS, 2010, p. 160).
\end{abstract}

$\mathrm{O}$ voto de Joaquim Barbosa é, também, acompanhado pelo ministro Marco Aurélio, o qual não admite contemporizações ou relativizações em aceitar qualquer forma intimidatória do Estado contra o contribuinte, destacando as Súmulas $n^{\text {os }} 70,323$ e 547, como base para evitar que o Estado obrigue o contribuinte a pagar tributo de forma diversa do previsto no Processo de Execução.

Posteriormente, aos vinte e nove dias do mês de maio do ano 2014, esse assunto voltou a ser pauta de decisão da Suprema Corte, no Recurso Extraordinário nº 565.048.

Tal recurso fora interposto a fim de assentar a legitimidade de a Fazenda Pública autorizar a impressão de talonários de notas fiscais, encontrando-se o contribuinte em mora quanto ao Imposto Sobre Circulação de Mercadorias e Serviços (ICMS), somente mediante a prestação, pelo devedor, de fiança idônea; garantia real ou outra fidejussória capaz de cobrir obrigações tributárias futuras decorrentes de operações mercantis presumidas.

Em seu voto, muito bem se posiciona o Senhor Ministro Relator Marco Aurélio, ao dispor que

http://stf.jus.br/portal/diarioJustica/verDiarioProcesso.asp?numDj=53\&dataPublicacaoDj=20/03/2009\&incidente $=1493516 \&$ codCapitulo=5\&numMateria=7\&codMateria=1. Acesso em: 29 de março de 2018 . 
"O tema não é novo, tendo sido enfrentado em diferentes oportunidades neste Plenário. Em julgados anteriores, entendi conflitantes com a Carta da República procedimentos dessa natureza. Conclui que a Fazenda deve buscar o Judiciário visando à cobrança, via executivo fiscal do que devido, mostrando-se impertinente recorrer a métodos que acabem inviabilizando a própria atividade econômica, como é o relativo à proibição de as empresas em débito ${ }^{1516 " .}$.

De fundamental importância para o presente trabalho, assim se manifestou o exministro Joaquim Barbosa:

\begin{abstract}
"Esta Suprema Corte tem uma venerável série de precedentes que consideram inconstitucionais quaisquer instrumentos de indução indireta, por sacrificios de direitos fundamentais, destinados a levar o sujeito passivo ao recolhimento do valor do tributo que se supõe devido. As chamadas sanções politicas são absolutamente incompativeis com a Constituição. Somente são admissíveis as medidas extremas se, em ponderacão, ficar demonstrado sem dúvida razoável que a intencão da pessoa iurídica é obter sistematicamente vantagens econômicas com a contumaz sonegacão. Porém, precisamos nos lembrar que a isolada falta de pagamento de valor do tributo, a inadimplência tributária, é insuficiente para caracterizar a intenção criminosa do sujeito passivo. (...) No caso em exame, a Fazenda Estadual não provou que o recorrente é empresa que deriva sua maior vantagem concorrencial de inadimplência preordenada e sistemática. Um empreendedor pode acumular dividas simplesmente por ser administrativamente inapto, ou por externalidades como situação econômica desfavorável ou concorrentes mais eficazes $^{17}$ ". (Grifo nosso)
\end{abstract}

No mesmo sentido votou o ministro Celso de Melo, além de o ministro Luís Roberto Barroso, que fez questão de "acompanhar e louvar o voto cuidadoso, detalhado e erudito do Ministro Marco Aurélio".

De igual forma ocorreu no julgado referente ao Agravo Regimental no Agravo de Instrumento $\mathrm{n}^{\circ} 623.739$, em que seu Acórdão estabelece a inconstitucionalidade de aplicação da sanção política visando ao recolhimento de tributo.

Em seu voto, o ministro relator Luís Roberto Barroso assim argumenta:

"Cumpre registrar que a Corte já se pronunciou acerca da inconstitucionalidade de medidas coercitivas, por parte do Fisco, objetivando a satisfação de débito tributário. Em sintese, é inconstitucional legislação local que submete o

\footnotetext{
${ }^{15}$ BRASIL. Supremo Tribunal Federal: Recurso Extraordinário 565.048, disponível em:http://redir.stf.jus.br/paginadorpub/paginador.jsp?docTP=TP\&docID=6911989. Acesso em: 2 de abril de 2018.

${ }^{16}$ BRASIL. Supremo Tribunal Federal: Recurso Extraordinário 565.048, disponível em:http://redir.stf.jus.br/paginadorpub/paginador.jsp?docTP=TP\&docID=6911989. Acesso em: 2 de abril de 2018.

${ }^{17}$ BRASIL. Supremo Tribunal Federal: Recurso Extraordinário 565.048, disponível em:http://redir.stf.jus.br/paginadorpub/paginador.jsp?docTP=TP\&docID=6911989. Acesso em: 2 de abril de 2018.
} 
contribuinte, quando em débito, à prestação de garantias reais ou fidejussórias para obter autorização alusiva à impressão de talonário de notas fiscais ${ }^{18}$."

Ademais, o ministro relator adverte que não se aplica ao caso apresentado o entendimento da Suprema Corte referente à $\mathrm{AC} \mathrm{n}^{\circ} 1.657 / \mathrm{RJ}$, por ser matéria diversa da analisada. Naquela hipótese, tratava-se de contribuinte sistematicamente inadimplente.

Por fim, em sede de Repercussão Geral no Recurso Extraordinário com Agravo $\mathrm{n}^{\circ}$ 914.045, houve, em 15 de outubro de 2015, a reafirmação da Jurisprudência que já vinha sendo adotada pela Suprema Corte.

O caso tratava de agravo interposto em face de decisão que inadmitiu recurso extraordinário contra acórdão do Tribunal de Justiça do Estado de Minas Gerais, que julgou prejudicada a Apelação apresentada pelo estado de Minas Gerais.

A Fazenda Pública Estadual havia condicionado o deferimento de inscrição em cadastro de produtor rural do contribuinte à regularização de débitos fiscais constantes em PTAs. Diante de tal fato, houve a impetração de Mandado de Segurança, por parte do sujeito passivo, a qual foi prontamente deferida pelo juiz de primeiro grau e, posteriormente, mantida pelo Tribunal de Justiça daquele Estado, que negou seguimento às matérias remanescentes com base na jurisprudência da Corte Maior.

Ao chegar ao Supremo Tribunal Federal, em seu relatório, assim se manifesta o ministro relator Edson Fachin:

"Constata-se que o acórdão recorrido não diverge da jurisprudência desta Corte, segundo a qual é inconstitucional a imposição de restrições ao exercício de atividade econômica ou profissional do contribuinte, quando este se encontra em débito para com o Fisco ${ }^{19}$."

De outro modo, o ministro Luís Roberto Barroso afirma ter dúvidas sobre a conveniência de uma reafirmação de jurisprudência nos termos propostos, pois, segundo ele, apesar da existência das Súmulas $n^{\circ}$ i 70,323 e 547 do STF, a matéria comporta sutilezas que devem ser mais bem discutidas em Plenário físico, haja vista que o Plenário da Corte já estipulou parâmetros para o exercício da atividade da indústria do cigarro em caso de inadimplência tributária:

${ }^{18}$ BRASIL. Supremo Tribunal Federa: AG. REG. NO AGRAVO DE INSTRUMENTO 623.739/RS, disponível em: http://redir.stf.jus.br/paginadorpub/paginador.jsp?docTP=TP\&docID=9232296, Acesso em: 2 de abril de 2018.

${ }^{19}$ BRASIL. Supremo Tribunal Federal: RECURSO EXTRAORDINÁRIO COM AGRAVO ARE 914045 RG/MG, disponível em: http://stf.jus.br/portal/jurisprudencia/listarJurisprudencia.asp?s1=\%28SAN\%C7\%C3O+POL \%CDTICA\%29\&ba se=baseRepercussao\&url=http://tinyurl.com/j96h3en, acesso em: 2 de abril de 2018 


\begin{abstract}
"Portanto, sem propriamente discordar do entendimento do Min. Edson Fachin, considero, no entanto, que o tema (ii) deveria ser melhor debatido em Plenário fisico, com todas as suas nuances. 13. Diante do exposto, manifesto-me no sentido do caráter constitucional e da repercussão geral de ambas as questões suscitadas, pela reafirmação da jurisprudência quanto à tese (i), e pela não reafirmação da iurisprudência quanto à tese (ii), para cuja apreciação me reservo em eventual iulgamento pelo Plenário físico ${ }^{20}$ ". (Grifo nosso)
\end{abstract}

Todavia, apesar dos posicionamentos contrários, o Supremo Tribunal Federal, por maioria, reconheceu a existência de repercussão geral da questão constitucional suscitada, vencido o ministro Marco Aurélio. Já no mérito, por maioria, reafirmou a jurisprudência dominante sobre a matéria, vencidos os ministros Marco Aurélio e Roberto Barroso.

De tal modo, a decisão do Supremo Tribunal Federal, diante dos casos apresentados, veio reforçar e ampliar o consolidado entendimento quanto à inconstitucionalidade da aplicação das sanções políticas, o que nos remete à conclusão de que o Supremo Tribunal Federal não mudou seu posicionamento no julgamento da Ação Cautelar n ${ }^{\circ}$ 1.657/RJ, bem como do $\mathrm{RE} \mathrm{n}^{\circ} 550.769 / \mathrm{RJ}$, ao permitir a interdição do estabelecimento, mas tão somente conferiu uma interpretação específica ao caso concreto.

Apesar de a Constituição da República Federativa do Brasil, em seu artigo 170, parágrafo único ${ }^{21}$, assegurar o livre exercício da atividade econômica, ela põe a salvo alguns casos em que necessitará de autorização do órgão público, visto que, conforme observado, a liberdade de iniciativa econômica não é absoluta, sendo possível, em determinados casos mais graves, a interdição de estabelecimento em respeito ao dever de pagar impostos, à livre concorrência, à justiça fiscal e, ainda, visando salvaguardar a contraface da prestação de benefícios coletivos (BATISTA JUNIOR, 2010, p. 457).

Nesse sentido, não há como discordar de quaisquer argumentos utilizados pelo Supremo Tribunal Federal, devendo-se ressaltar a defesa da interdição ou restrição de direitos fiscais nos casos em que houver comprovado a fraude ou a má fé na intenção de burlar a Administração Tributária.

\footnotetext{
${ }^{20}$ BRASIL. Supremo Tribunal Federal: RECURSO EXTRAORDINÁRIO COM AGRAVO ARE 914045 RG / MG, disponível em:

http://stf.jus.br/portal/jurisprudencia/listarJurisprudencia.asp?s1=\%28SAN $\% \mathrm{C} 7 \% \mathrm{C} 3 \mathrm{O}+\mathrm{POL} \% \mathrm{CDTICA} \% 29 \& \mathrm{ba}$ se=baseRepercussao\&url=http://tinyurl.com/j96h3en, acesso em: 2 de abril de 2018 .

${ }^{21}$ BRASIL. Constituição (1988). Constituição da República Federativa do Brasil: Senado, 1988.
} 


\section{CONCLUSÃO}

É por meio da tributação que o Estado irá prover as necessidades coletivas, bem como os direitos fundamentais de seus cidadãos. Porém, existem empresas que buscam constantemente se eximir dessa responsabilidade, seja pela sonegação fiscal ou pelo inadimplemento da obrigação tributária. Para esses casos, o direito tributário reserva a aplicação de algumas sanções tributárias, entre elas as denominadas: sanções políticas.

Foi apresentada, no presente trabalho, a divergência doutrinária no que tange ao tema exposto. Foram apresentadas, também, algumas decisões do Supremo Tribunal Federal, comprovando que este sempre se posicionou contrário a qualquer tipo de restrição imposta ao contribuinte no intuito de compeli-lo ao pagamento do tributo devido. Houve, contudo, uma grande novidade em relação ao caso da empresa de cigarros América Virginia Tabacos, por ser esta titular de uma dívida de 1,42 bilhões, devido ao não recolhimento do Imposto sobre Produtos Industrializados (IPI), o que permitiu acelerada e crescente acumulação de riqueza pelo não pagamento de tributo e, consequentemente, pela concorrência desleal.

A par disso, após a comprovação de inadimplemento tributário por parte da referida empresa, houve a interdição do estabelecimento, que pretensamente consistiria em uma das três formas de sanções políticas vedadas pelo Supremo Tribunal Federal.

Ocorre que, com as posteriores decisões proferidas pela Suprema Corte envolvendo novamente as sanções políticas, ficou comprovada a não alteração da Jurisprudência, haja vista que a aplicação dessas sanções continua sendo considerada inconstitucional por essa Corte, prevalecendo o entendimento de que houve tão somente uma interpretação específica ao caso concreto, tendo em conta a singularidade factual e normativa do caso analisado.

De fato, a interdição do estabelecimento não pode se transformar em mecanismo de cobrança de débitos fiscais. Contudo, em situações em que se detectar reiterada prática de inadimplemento tributário, quando o interesse público encontrar-se lesado, quando a livre concorrência, isonomia, boa-fé e segurança jurídica se acharem ameaçadas, torna-se possível e necessária, como medida de exceção, a aplicação de determinadas restrições com o escopo de assegurar a ordem jurídica tributária.

Dessa forma, conclui-se sobre a necessidade de revisão no que tange à interpretação, bem como à aplicação de determinadas restrições pelo Supremo Tribunal Federal, no intuito de que estas possam ser utilizadas de acordo com o caso especifico, aplicando sempre que necessária a manutenção da ordem jurídica e econômica. Pois, concordando com o posicionamento de Dutra (2010, p. 22), a compreensão que havia se formado, doutrinaria e 
jurisprudencialmente, acerca da ilegitimidade de determinadas restrições, não mais se compatibiliza com o Estado Democrático de Direito adotado pela Constituição da República Federativa do Brasil, de 1988, que, ao reafirmar o caráter tributário do Estado brasileiro e consagrar uma série de bens públicos, os quais devem ser fornecidos aos cidadãos, consagra, também, a existência do dever fundamental de pagar tributos.

\section{REFERÊNCIAS}

BATISTA JÚNIOR, Onofre Alves. As sanções administrativo-fiscais heterodoxas e sua cuidadosa possibilidade de aplicação no direito tributário. In: SILVA, Paulo Roberto Coimbra (Coord.). Grandes temas do Direito Tributário Sancionador. São Paulo: QuartierLatin, 2010. p. 427 - 464.

BECCARIA, Cesare. Dos Delitos e das Penas. Trad. Paulo M. Oliveira. Rio de Janeiro:Ediouro, 1985, p. 123.

BOBBIO, Norberto. Teoria do ordenamento jurídico. 10. ed. Brasília: Ed. UnB, 1999. 184p.

BRASIL. Código Tributário Nacional (1966). Código Tributário Nacional: Senado, 1966.

BRASIL. Constituição (1988). Constituição da República Federativa do Brasil: Senado, 1988.

BRASIL. Supremo Tribunal Federal - STF. Institucional. Disponível em:

http://www.stf.jus.br/portal/cms/verTexto.asp?servico=sobreStfConhecaStfInstitucional, Acesso em: 2 de abril de 2018.

BRASIL. Supremo Tribunal Federal. Ação Direta de Inconstitucionalidade - ADI n 173. Constitucional. Min. Rel. ministro Joaquim Barbosa. Diário de Justiça da União, Brasília, 20 mar. 2009. Disponível em:

http://stf.jus.br/portal/diarioJustica/verDiarioProcesso.asp?numDj=53\&dataPublicacaoDj=20/ 03/2009\&incidente $=1493516 \&$ codCapitulo $=5 \&$ numMateria $=7 \&$ codMateria $=1$. Acesso em: 2 de abril de 2018.

BRASIL. Supremo Tribunal Federal. Ação Direta de Inconstitucionalidade - ADI no 394. Constitucional. Min. Rel. Joaquim Barbosa. Diário de Justiça da União, Brasília, 20 mar. 2009. Disponível em:

http://stf.jus.br/portal/diarioJustica/verDiarioProcesso.asp? numDj=53\&dataPublicacaoDj=20/ 03/2009\&incidente $=1493516 \&$ codCapitulo $=5 \&$ numMateria $=7 \&$ codMateria $=1$. Acesso em: 2 de abril de 2018.

BRASIL. Supremo Tribunal Federal. Ação Direta de Inconstitucionalidade - ADI nº 3.453. Distrito Federal. Min. Rel. Carmen Lúcia. Diário de Justiça da União, Brasília, 16 mar. 2007. Disponível em:

http://stf.jus.br/portal/jurisprudencia/listarJurisprudencia.asp?s1=\%28ADI\%24\%2ESCLA $\% 2$ 
$\mathrm{E}+\mathrm{E}+3453 \% 2 \mathrm{ENUME} \% 2 \mathrm{E} \% 29+\mathrm{OU}+\% 28 \mathrm{ADI} \% 2 \mathrm{EACMS} \% 2 \mathrm{E}+\mathrm{ADJ} 3453 \% 2 \mathrm{EACMS} \% 2 \mathrm{E}$ $\% 29 \&$ base=baseAcordaos. Acesso em: 2 de abril de 2018.

BRASIL. Supremo Tribunal Federal. Recurso Extraordinário. RE 374.981. Min. Rel. Celso de Mello. Diário de Justiça da União, Brasília, 8 abr. 2005. Disponível em:

http://www.stf.jus.br/portal/jurisprudencia/listarJurisprudencia.asp?s1=\%28\%28374981\%2E NUME $\% 2 \mathrm{E}+\mathrm{OU}+374981 \% 2 \mathrm{EDMS} \% 2 \mathrm{E} \% 29 \% 29+\mathrm{NAO}+\mathrm{S} \% 2 \mathrm{EPRES} \% 2 \mathrm{E} \&$ base=baseMono craticas. Acesso em: 2 de abril de 2018.

BRASIL. Supremo Tribunal Federal. Recurso Extraordinário. RE 523.366. Rel. ministro Celso de Mello. Diário de Justiça da União, Brasília, 9 mar. 2007. Disponível em: http://www.stf.jus.br/portal/jurisprudencia/listarJurisprudencia.asp?s1=\%28\%28523366\%2E NUME $\% 2 \mathrm{E}+\mathrm{OU}+523366 \% 2 \mathrm{EDMS} \% 2 \mathrm{E} \% 29 \% 29+\mathrm{NAO}+\mathrm{S} \% 2 \mathrm{EPRES} \% 2 \mathrm{E} \&$ base=baseMono craticas. Acesso em: 2 de abril de 2018.

BRASIL. Supremo Tribunal Federal. Recurso Extraordinário. AC 1.657-6. Rel. ministro Cezar Peluso. Diário de Justiça da União, Brasília, 31 ago. 2007.

BRASIL. Supremo Tribunal Federal: Recurso Extraordinário 565.048, disponível em:http://redir.stf.jus.br/paginadorpub/paginador.jsp?docTP=TP\&docID=6911989. Acesso em: 15 de março de 2018.

BRASIL. Supremo Tribunal Federal: AG. REG. NO AGRAVO DE INSTRUMENTO 623.739/RS, disponível em:

http://redir.stf.jus.br/paginadorpub/paginador.jsp?docTP=TP\&docID=9232296, Acesso em: 15 de março de 2018.

BRASIL. Supremo Tribunal Federal: RECURSO EXTRAORDINÁRIO COM AGRAVO ARE 914045 RG / MG, disponível

em:http://stf.jus.br/portal/jurisprudencia/listarJurisprudencia.asp?s1 $=\% 28 \mathrm{SAN} \% \mathrm{C} 7 \% \mathrm{C} 3 \mathrm{O}+\mathrm{P}$ OL\%CDTICA\%29\&base=baseRepercussao\&url=http://tinyurl.com/j96h3en, acesso em: 2 de abril de 2018.

BRASIL. Supremo Tribunal Federal. Súmula 70. É inadmissível a interdição de estabelecimento como meio coercitivo para cobrança de tributo. Súmula da Jurisprudência Predominante do Supremo Tribunal Federal: Anexo ao Regimento Interno. Edição: Imprensa Nacional, 1964a, p. 56.

BRASIL. Supremo Tribunal Federal. Súmula 323. É inadmissível a apreensão de mercadorias como meio coercitivo para pagamento de tributos. Súmula da Jurisprudência Predominante do Supremo Tribunal Federal: Anexo ao Regimento Interno. Edição: Imprensa Nacional, 1964b, p. 143.

BRASIL. Supremo Tribunal Federal. Súmula 547. Não é lícito à autoridade proibir que o contribuinte em débito adquira estampilhas, despache mercadorias nas alfândegas e exerça suas atividades profissionais. Diário de Justiça da União, Brasília, 10 de dezembro de 1969, p. 5.935 .

DIANIN. Irene Maria Brzezinski. Aspectos Relevantes do Ilícito Tributário no Sistema Tributário Nacional. São Paulo: Editora Resenha Tributária, 1991, 126 p. 
DUTRA, Adriano Antônio Gomes. A legitimidade das sanções políticas tributárias na perspectiva do dever fundamental de pagar tributos. Direito Público: Revista Jurídica da Advocacia-Geral do Estado de Minas Gerais. Belo Horizonte, nº. 1/2, p. 9-25, jan./dez. 2010.

FEITOSA, Airton Gondim: Sanções Políticas “IN TRIBUTOS”. Disponível em: www.portaltributario.com.br/artigos/sancoespoliticas.htm, acesso em: 30 de janeiro de 2018.

GANDARA. Leonardo André. Sanções Políticas Morais e Indiretas: Usos de Mecanismos Institucionais da Sanção Tributária e Breves Comentários Sobre a Influência no Mercado de Cigarros. In: Carlos Roberto Coimbra Silva. Grandes temas do Direito Tributário Sancionador. São Paulo: QuartierLatin, 2010. p. 305 -322.

GANDARA, Leonardo André. Sanções políticas e o direito tributário: permeabilidade com os princípios constitucionais tributários e admissibilidade sob o prisma do estado democrático de direito. 2012. 202 f. Dissertação (Mestrado) - Pontifícia Universidade Católica de Minas Gerais, Programa de Pós-Graduação em Direito.

GOMES, Nuno de Sá. Evasão Fiscal, Infracção Fiscal e Processo Penal Fiscal. Rei dos Livros. Portugal. 2000. p. 390.

KELSEN. Hans. Teoria Pura do Direito. Trad. João B. Machado. São Paulo: Martins Fontes, 2003.

MACHADO, Hugo de Brito; MACHADO SEGUNDO, Hugo de Brito. Sanções políticas como meio coercitivo na cobrança de tributo. Incompatibilidade com as garantias constitucionais do contribuinte. Efeito suspensivo a recurso extraordinário. Requisitos da medida cautelar. Revista Dialética de Direito Tributário, São Paulo, n. 150, p.85-101, mar. 2008.

MACHADO. Hugo de Britto: Sanções Políticas no Direito Tributário . Revista Dialética de Direito Tributário. São Paulo, nº 30. p. 46 e 47, 2010.

PAULSEN. Leandro: Direito Tributário: Constituição e Código Tributário a Luz da Doutrina e da Jurisprudência. $11^{a}$ ed. Porto Alegre: Livraria do Advogado Ed itora; ESMAFE, 2009.

PEREZ. Juan J, El sistema de infraciones y sanciones tributátias (los princípios constitucionalesdelderecho sancionador). Madrid: Civitas, 1992.

SAINZ DE BANJADA, Fernando. Sistema de Derecho Financeiro. T. I, v. $2^{\circ}$, Madrid: Facultad de Derecho de laUniversidadComplutense, 1985.

SILVA. Isabel Marques da. Regime Geral das Infracções Tributárias / Isabel Marques da

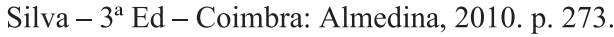

SILVA, Paulo Roberto Coimbra: Direito Tributário Sancionador. São Paulo: QuartierLatin, 2007. 
SILVA, Paulo Roberto Coimbra. A Responsabilidade pela Prática de Infrações Fiscais Principais Correntes e a Evolução do Tema na América Latina. In: Paulo Roberto Coimbra Silva (Coord.). Grandes temas do Direito Tributário Sancionador. São Paulo: QuartierLatin, 2010. p. $465-484$.

SOBRINHO, Suian Alencar: sanções políticas no direito tributário: abuso do poder de tributar em circunstancias fatuais, Disponível em:

http://web.unifacs.br/revistajuridica/edicao_dezembro2005/docente/doc_02.doc, acesso em: 20 de abril de 2016. 